\title{
SALPA DEMOCRATICA.
}

Q

CHARACTER GENERICUS.

Corpus liberum, gelatinofum, utroque apice aperto, intus vacuum; inteftino obliquo. Lin. Syft. Nat. Gmel. p. 3129.

CHARACTER SPECIFICUS, EंC.

SALPA fafciata, poftice aculeata.

SALPA punctata, fafciata, aculeis pone octo. Lin. Syf Nat. Gmel. p. 3 I 29. Forkk. Fn. Aegypt. Arab. p. 113. n. 32.

Natat, ut plurimum, hæc fpecies nullo certo tramite, agmine quaquaverfum confufo, fine ullo duce aut confilio; quam ob caufam conjicio Dominum Forfkal, qui forfan primus eam defcripfit democraticam nominaffe. Salpæ fere omnes in mari mediterraneo nafcuntur, democratica autem præcipue in mari rubro. 


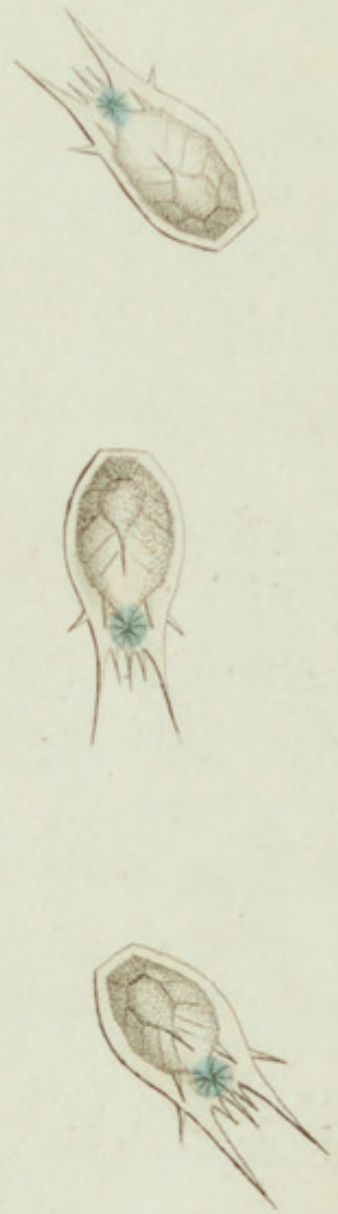
THE

\section{DEMOCRATIC SALPA.}

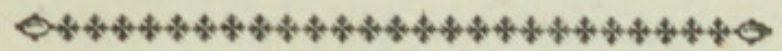

GENERIC CHARACTER.

Body tubular, nayant, gelatinous, open at each extremity, furnifhed with an oblique inteftine.

SPECIFIC CHARACTER.

FASCIATED SALPA, aculeated behind.

The fpecies of Salpa here reprefented is generally feen in large groupes or multitudes, fwimming confufedly in all directions, without any leader, plan or order; for which reafon Mr. Forfkall, its firft defcriber, feems to have applied to it the title by which it is at prefent diftinguifhed. Almoft all the Salpx are natives of the Mediterranean, but this is principally found in the red fea. 


\section{$2 \mathrm{BHL}$ Biodiversity Heritage Library}

Shaw, George. 1796. "The Democratic Salpa, Salpa democratica [PI. 236]." The Naturalist's Miscellany 7(LXXIX), https://doi.org/10.5962/p.310779.

View This Item Online: https://www.biodiversitylibrary.org/item/276356

DOI: https://doi.org/10.5962/p.310779

Permalink: https://www.biodiversitylibrary.org/partpdf/310779

\section{Holding Institution}

Museums Victoria

\section{Sponsored by}

Atlas of Living Australia

\section{Copyright \& Reuse}

Copyright Status: Public domain. The BHL considers that this work is no longer under copyright protection.

This document was created from content at the Biodiversity Heritage Library, the world's largest open access digital library for biodiversity literature and archives. Visit BHL at https://www.biodiversitylibrary.org. 